\title{
The Role of Mothers in Media Literacy Assistance to Digital Native Children in Semarang
}

\author{
Ana Irhandayaningsih, Yuli Rohmiyati \\ \{yulirohmiyati@gmail.com\} \\ Department of Library Science, Faculty of Humanities, Diponegoro University \\ J1. Prof. Soedarto, S.H. Undip Tembalang, Semarang, Central Java - Indonesia, 50275
}

\begin{abstract}
The presence of technology of information and communication in Indonesia is astounding when it comes to the improvement of performances in various sectors. However, the information technology appears to progress beyond the ability of Indonesian society to embrace it, especially for children and mothers. The objectives of this research are: to analyze mothers' role in assisting digital native children's use of mobile phones, to identify the characteristics of digital native children in Semarang, to describe the form of mothers' assistance to digital native children in Semarang, and to formulate a model of strengthening the role of mothers in assisting digital native children in the coastal region. Mother role in assisting children in using the native digital media/mobile phones in terms of supervision, manufacturing agreements, and assistance on any matter that is accessible to children. The characters that appear on digital native children in Semarang become responsible, open, communicative. The impact of the use of information technology in the digital native children in Semarang has more friends, does not miss any information, and friendship. The mother form of assistance to the digital native children in Semarang is in the form of questions, giving directions, and strengthening the activities of children associated with mobile media.
\end{abstract}

Keywords: Media Literac; Mothers; Digital Native; Semarang.

\section{Introduction}

The presence of technology of information and communication in Indonesia is astounding when it comes to the improvement of performances in various sectors. However, the information technology appears to progress beyond the ability of Indonesian society to embrace it, especially for children and mothers.

The phenomena of cyberbullying, online games addiction, psychological disorders, and children's achievement deterioration are some of the adverse effects that concern mothers. Media literacy competencies, thus, have to be acquired by mothers. Mothers' assistance in media consumption is a necessity. Mothers need to actively control children in consuming the media such as television, mobile phones, and computers (Awaluddin, 2009).

The public's awareness of media literacy needs to be raised starting from the family institution. Therefore, the next generation will be strengthened and will not perceive information technology as a threat to national and intellectual values. On the contrary, it will bring them closer to a better civilization.

The problem is, the lack of communication between mothers and children is caused by the use of technology that leads to selfishness, individuality, and a decrease in social sensitivity. It can alter the national attitude into selfishness, individuality, and impunity. In the coastal region, most mothers are occupied with work so that their children receive less parental assistance in their use of technology. The objectives of this research are (1) To analyze mothers' 
role in assisting digital native children's use of mobile phones; (2) To identify the characteristics of digital native children in Semarang; (3) To describe the form of mothers' assistance to digital native children in Semarang; (4) To formulate a model of strengthening the role of mothers in assisting digital native children in the coastal region.

\section{Method}

This study used qualitative research methods. Methods of collecting data are through interviews, observation, and literature. The subject of this research is mothers who have children up to the age of eighteen. This research carried out in Semarang.

\section{Literature Review}

The media is a mass communication device, solely for convenience reasons. But in relation to media literacy, the media are interpreted as: (1) Tools and material for transmitting information; (2) Medium for recording and protecting information; (3) Information or messages distributed in the media.

Media literacy is conceptualized as "... the ability to access, analyze, evaluate and create messages across a variety of contexts (Livingstone, 2003)." This concept is applied to a variety of ideas that seek to explain how the media convey their messages, and why. Rubin in Prihandini (2007) explains three definitions of media literacy. First, the ability to access, analyze, evaluate and communicate messages. Second, namely knowledge of how the media function in society. Third, namely understanding culture, economics, politics and the imposition of technology in creating, producing and transmitting messages.

The concept of media literacy was first thought to emerge in the 1980s, and has now become a standard topic of study in schools in various countries. Logically understandable, this concept did not emerge from the media, but from activists and academics who were concerned with the adverse effects of mass media controlled by capitalist forces to deny the public interest. The thought of a number of prominent communication-philosophers led to the birth of the concept of media literacy. Sonia Livingstone (2004) noted figures such as Canadian communication theorist Marshall McLuhan, American Critical linguist Noam Chomsky, French philosopher Jean Baudrillard, US communications critic Neil Postman, and a pioneer of American media education: Renee Hobbs.

The theoretical foundation of media literacy itself comes from the tradition of left thinking, which developed in cultural studies (Leftist Cultural Studies). As Livingstone (2004) stated, media literacy is "... a synthesizer of media education projects dating back to $1920 \mathrm{~s}$... act as an umbrella term for teaching practices that make students aware of the constructs of mass media." Media literacy is often mistaken for media education . Indeed, media literacy needs to be distinguished from media education. Media literacy is not media education, although the latter is often part of the first. Media education views the media in a function that is always positive, namely as a site of pleasure in various forms. While media literacy using the inocculationist approach seeks to protect children from what is perceived as a bad effect on the mass media.

The use of media and media products as part of the teaching and learning process, for example learning how to produce independent films or using newspapers as a source of data tracking, belongs to media education. The media literacy goes further than that. With a more critical approach, media literacy not only studies aspects of production, but also studies what 
possibilities can arise due to the power of media. Media literacy teaches the public to use the media critically and wisely (Astuty, 2007).

Meanwhile Silverblatt's (in Baran 2012) defines five elements of media literacy; 1) Awareness of the impact of mass media on individuals and society, 2) understanding of the process of mass communication, 3) Development of strategies to analyze and discuss media messages, 4) Awareness of media content as texts that provide input for contemporary culture and ourselves, 5) Processing pleasure towards the media, understanding and appreciation of media content. The key elements in media literacy are media literacy is not limited to one medium, requires skills, requires a certain type of knowledge and is always related to Potter's values (in Adiputra, 2009).

\section{Results}

According to the data, in Semarang, the digital native children in using their gadget/phone and for children who are also used to carry cell phones, they tend to still converse with friends. Seeing those conditions, the role of a mother in terms of mentoring teenage boys turned out anyway the mothers want. The results of this study have shown that these mothers stay with their children in a way to watch what they can do with their gadget/mobile phone. The surveillance also did by asking what they can do with their gadgets. Usually, children will actually tell you a lot and show whatever news they get from the media.

The mentoring role of the mother is seen in the making of agreements they make with their children. For example, one of the informants said that he allowed his son to bring his gadget but he still has to focus on his school and does not decrease his school achievement. The mothers also restrict their children's access to their gadgets. They are only allowed to use the gadget after school.

As for the characters that appear on digital native children in Semarang, the character is an attitude that comes from the pattern of the caring and education that the children get in the process of development. Characters that appear on the digital native children in Semarang tend to be more open. The children often show their mothers what they can do or see from their gadgets. The children convey the status of their friends and even the status of other mothers who live in Semarang along with their sisters. It occurs in one of the informants as the informant does not have the gadget.

The digital native children tend to be more open, making communication between mothers and their children are more intensively. Mothers can monitor and direct their children in the use of their gadgets. Thus, the relationship between mother and child becomes warmer and closer.

The other character that appears is the responsible attitude. One of the informants stated that their children have gadgets for the result of their own savings. It turned out to affect the way the child maintain and use such gadgets. He was more cautious in using gadgets.

The impact of the use of media gadget/phone in children in Semarang is that information technology can be used to access the information, one of which is the gadget. The digital native children in Semarang access information related to their lessons and some social media used by friends and some residents of the region. This resulted in an increasingly broad friendship. Children can get to know more closely with their friends and neighbors. Another impact of the use of these gadgets is that their friendship or kinship is tightened so that the relationship is improved. One of the informants said that their children often break the news about their friends and their neighbors in the region. 
Another thing that is obtained is that children are more updated information. They do not miss the homework or an update of the news of and they convey them to their mothers.

The form of mothers' assistance towards digital native children in Semarang is visible from the mothers who often asked or saw any of their gadgets. One of the informants stated that children are mostly viewed as pictures of friends or relatives. The mothers also do a reinforcement to their children. As their children play with their siblings in their home, the mothers also remind them of the time of their test/exam and they should pay more attention to their lessons. The scheme codes of the digital native children are: (1) Tend to be more open in cyberspace; (2) Free but controlled; (3) Has character of unlimited socio-communal; (4) Individualist in the real world. Menawhile, scheme impacts of media/mobile phones for children are: (1) Access negative information; (2) Plenty of information; (3) Closer communication links; (4) Children apathy towards the environment; (5) The dependence on gadgets.

\section{Conclusion}

Mothers' role in assisting the digital native children in using mobile phones in terms of supervision, manufacturing agreements, and assistance on other matters that is accessible to children. The characters that appear on digital native children in Semarang become responsible, open, communicative.

The characteristics of digital native children in Semarang are they have more friends, do not miss the information, and friendship. The mother form of assistance to the digital native children in Semarang is in the form of questions, giving directions, and strengthening the activities of children associated with mobile media.

\section{References}

[1] Awaludin, Wahyu.: Fenomena Generasi Digital Native 25 November 2009 http://www.kompasiana.com/wahyu.awaludin/fenomena-generasi-digitalnative_54ff29aaa333110f4550fc2b.

[2] Suryadi , Israwati.: Kajian Perilaku Menonton Tayangan TV dan Pendidikan Literasi Media Pada Remaja . Jurnal Academika Fisip Untad: Vol 5,No 01 Feb (2013).

[3] Triputra, Pinkey.: Dilema Industri Penyiaran di Indonesia: Studi tentang Neoliberalisme dan Perkembangan Pertelevisian di Era Orde Baru dan Reformasi. Disertasi. Jakarta. Universitas Indonesia. (2004) 